\title{
ROMANIAN PATIENTS WHO EXPERIENCE IN-STENT RESTENOSIS AFTER ST-ELEVATION MYOCARDIAL INFARCTION: THE EXPERIENCE OF A TERTIARY CENTER
}

\author{
Alice Elena Munteanu, Liviu Chiriac, Filip Romi Bolohan, Daniel Niță, \\ Ruxandra Constantinescu, Iulia Theodora Ioniță, Mihnea Casian \\ Center of Cardiovascular Diseases, "Dr. Carol Davila" Central Universyty Emergency Military \\ Hospital, Bucharest, Romania \\ Corresponding author: Munteanu Alice Elena \\ E:mail: dralicepopescu@yahoo.com
}

\begin{abstract}
Background and aim. Coronary artery disease (CAD) is one of the most important causes of death worldwide. ST-elevation myocardial infarction (STEMI) is an acute form of presentation in patients with CAD. Percutaneous coronary intervention (PCI) is the treatment of choice in STEMI patients. Generally, a stent is placed after the culprit lesion is dilated in order to ensure the patency of the coronary artery. In-stent restenosis (ISR) is a possible chronic complication in this setting. The following study is one of the few of its kind, since it investigates ISR in a cohort of Romanian patients who underwent PCI in the setting of STEMI. Our current descriptive study aims at highlighting the characteristics of these patients and identifying potential risk factors in this specific population, which could be validated by a further larger study.
\end{abstract}

Methods. We studied 68 patients from "Dr. Carol Davila" Central Military Emergency University Hospital in Bucharest, Romania, who presented with STEMI in 2016. The mean time for angiographic reevaluation was 111 days.

Results. 94\% (64) of the patients underwent primary $P C l$, while in 6\% (4) of the cases thrombolysis was initially attempted before $\mathrm{PCl}$. The most prevalent risk factors that we identified were: arterial hypertension (61\%), dyslipidemia (60\%) and smoking or history of smoking (47\%). The anterior myocardial infarction was the most prevalent (49\%). Only $6 \%$ of the patients had a documented history of CAD, while on the other hand chronic occlusions were observed in most patients (85\%). Of note is that only $11 \%$ of the patients reported recurrent angina before the angiographic reevaluation.

Conclusion. Common cardiovascular risk factors are also involved in ISR. Their poor management in the case of Romanian patients with STEMI increases the risk of ISR. The lack of symptoms in patients with ISR constitutes a warning sign for clinicians and shows that ISR is a complication which can be easily omitted. Therefore, its incidence is probably underestimated.

Keywords: STEMI, stent, $P C I$, restenosis, CAD, Romanian. 


\section{INTERNAL}

\section{Original Papers}

\section{Rezumat}

Boala coronariană ischemică (BCl) este una dintre cele mai importante cauze de deces la nivel mondial. Infarctul miocardic cu supradenivelare de segment ST (STEMI) este o formă acută de prezentare a $\mathrm{BCl}$, în care tratamentul de primă intenție îl reprezintă revascularizarea miocardică prin angioplastie cu balon și implantarea unui stent care asigură patența arterei coronare dilatate. Restenoza reprezintă o potențială complicație pe termen lung la pacienții anterior stentați. Lucrarea de față este printre primele din România care investighează o cohortă de pacienți cu restenoză intrastent ca urmare a tratamentului intervențional pentru STEMI. Studiul nostru descriptiv are ca scop evidențierea caracteristicilor acestor pacienți și identificarea unor factori de risc care ar putea fi validați și aprofundați de studii ulterioare mai ample.

Material și metodă. Au fost studiați 68 de pacienți din Spitalul Universitar de Urgență Militar Central "Dr. Carol Davila" diagnosticați cu STEMI și tratați intervențional în cadrul programului STEMI. Timpul mediu pentru efactuarea reevaluării angiografice a fost de 111 zile.

Rezultate. Cei mai mulți dintre pacienți (94\%) au fost tratați intervențional per primam, în timp ce la 6\% dintre aceștia a fost încercată tromboliza în teritoriu, angioplastia fiind efectuată ulterior. Cei mai prevalenți factori de risc au fost: hipertensiunea arterială (61\%), dislipidemia (60\%) și fumatul sau istoricul de fumat (47\%). În cele mai multe cazuri (49\%) a fost implicat teritoriul anterior. Doar $6 \%$ dintre pacienți aveau istoric de $\mathrm{BCl}$, în timp ce ocluziile coronariene cronice au fost constatate angiografic în 85\% dintre cazuri. Relevant este și faptul că doar 11\% dintre pacienți au descris dureri anginoase recurente care să ridice suspiciunea de restenoză intrastent.

Concluzie. Factorii tradiționali de risc cardiovascular sunt regăsiți și la pacienții cu restenoză intrastent, iar controlul deficitar al acestora crește riscul de restenoză. Lipsa simptomelor sau simptomatologia nespecifică, în multe dintre cazuri, face ca restenoza să fie o complicație ușor de omis de către clinicieni. Din acest motiv, incidența ei reală este probabil subestimată în România.

Cuvinte cheie: STEMI, stent, angioplastie, restenoză, boală coronariană ischemică (BCI) 


\section{Introduction}

Cardiovascular diseases (CVDs) are the most important cause of death worldwide with myocardial infarction and stroke accounting for almost $4 / 5$ deaths of the entire cardiovascular related deaths ${ }^{(1)}$. CAD is actually a broad spectrum of diseases which includes two main clinical entities, different in approach and prognosis: chronic coronary syndromes (stable angina) and acute coronary syndromes. Acute coronary syndromes are further divided into three main categories based on the severity of the myocardial ischemia: unstable angina, nonST-elevation myocardial infarction (NSTEMI) and STEMI. STEMI represents a critical situation of myocardial ischemia in which the timely restoration of coronary blood flow is essential in order to avoid irreversible myocardial damage. The complications which arise in STEMI patients account for the high mortality rates and they include: acute left ventricular failure with cardiogenic shock, left ventricular free wall rupture, cardiac tamponade and ventricular arrhythmias. Since the introduction and validation of $\mathrm{PCl}$ as the method of choice for acute myocardial infarction with ST-elevation, the 30 days mortality rates dropped to $2,5-10 \%{ }^{(2)}$. Unfortunately, complications can occur even after $\mathrm{PCl}$ and they can be procedure-related or stent-related. The most common stentrelated complications are thrombosis (which is typically a short-term complication) and instent restenosis, which is a long-term complication. It can occur anytime, even 4 years after the $\mathrm{PCl}$, but it is more common in the first 3-9 months after the procedure ${ }^{(3)}$. The real incidence of ISR is probably underestimated, ranging from $17-41 \%$ in the case of bare-metal stents (BMS) to less than $10 \%$ in the case of second generation drug- eluting stents $(D E S)^{(4)}$. ISR is in fact just another stage in the CAD continuum which demonstrates the fact that CAD is a dynamic and perpetual process, affecting all coronary arteries, including those which were previously treated.

\section{Material and methods}

Our study included 68 patients from "Dr. Carol Davila" Central Military Emergency University Hospital of Bucharest who were diagnosed with STEMI and treated with $\mathrm{PCl}$ in the STEMI National Program and who developed ISR at the site of the implanted stent. The meantime between the first $\mathrm{PCl}$ and the second $\mathrm{PCl}$ was 111 days (91 days352 days). We defined ISR clinically as a stenosis greater than $50 \%$ in a previously treated coronary artery segment with at least one of the following signs or symptoms: recurrent angina, ECG changes in the territory of the treated vessel at rest or in the setting of exercise stress test. Also, we defined ISR in asymptomatic patients in which the target lesion revascularization (TLR- repeat $\mathrm{PCl}$ of the target lesion performed because of a suspected complication) showed a stenosis greater than $70 \%$ in the previously treated coronary artery segment.

\section{Results}

We begin by assessing the general characteristics of our cohort. The majority of patients are male $(49,72 \%)$, while only $28 \%$ (19) are female. The average age is 61 years, with the youngest patient being 36 years old and the oldest 85 years old (see Figure 1 ). Common cardiovascular risk factors were also investigated, such as: smoking (active or history of smoking), arterial hypertension, 


\section{INTERNAI}

\section{Original Papers}

diabetes mellitus (DM), obesity (IMC >30) and dyslipidemia. We observed that in $21 \%$ (16) of the cases, no cardiovascular risk factors were identified, however in $27 \%$ (18), two cardiovascular risk factors were associated (see Figure 2).

The prevalence of each cardiovascular risk factor among the studied population is as follows: arterial hypertension (61\%, 39), dyslipidemia $(60 \%, 38)$, smoking or history of smoking $(47 \%, 30)$, obesity $(29 \%, 20)$ and DM $(18 \%, 12)$, with only $17 \%$ (2) of the diabetic patients following an insulin regimen. We also looked into their associated cardiovascular diseases, finding that $13 \%$ (9) of our patients had a prior cardiovascular disease, such as: stroke $(6 \%, 4), \operatorname{CAD}(6 \%, 4)$ and peripheral artery disease $(1,5 \%, 1)$.

Thrombolysis was performed only in $6 \%$ (4) of the cases, with $94 \%$ (64) of the patients undergoing primary $\mathrm{PCl}$. With regard to the myocardial infarction itself, $49 \%$ (33) of the patients were diagnosed with anterior STEMI, $40 \%$ (27) with posterior-inferior STEMI and $11 \%$ (8) with lateral STEMI. As expected, in $46 \%$ (31) of the cases, the restenosis occurred on the anterior descending artery (ADA) stent, while the right coronary artery was involved in $40 \%$ (27) of the restenosis cases. The left main coronary artery was involved only in $3 \%(2)$ of the cases. Of note is that at the time of the diagnosis, $79 \%$ (54) of the patients had at least one other significant coronary lesion and the vast majority of the culprit lesions, $85 \%$ of them (58) appeared to be chronic occlusions. We also determined which Killip class was most frequent in patients who developed restenosis (see Figure 3 ), noticing that $40 \%$ (27) of the patients presented as Killip Class II.

Regarding the stents used, the majority $(88 \%, 60)$ were first-generation drug-eluting stents (DES), coated with sirolimus or paclitaxel, and only a minority $(12 \%, 8)$ were bare metal stents (BMS). We noticed that $38 \%$ (25) of the stents in which restenosis occurred were longer than $28 \mathrm{~mm}$ and $66 \%$ (45) of them occurred in vessels with a diameter smaller than $2.5 \mathrm{~mm}$.

Only a minority $(11 \%, 6)$ of patients with restenosis complained of recurrent angina. We also observed that $15 \%$ (10) of the patients had a positive stress ECG test which suggested ischemia in the territory supplied by the stented coronary artery. Regardless of the symptoms, $98,5 \%$ (67) of the restenosis were greater than $70 \%$.

\section{Discussions}

Restenosis is a poorly understood complication. Traditional cardiovascular risk factors are generally associated with restenosis, especially DM, with some authors suggesting a higher risk for patients on insulin regimens ${ }^{(5)}$. In our cohort, DM had a lower 


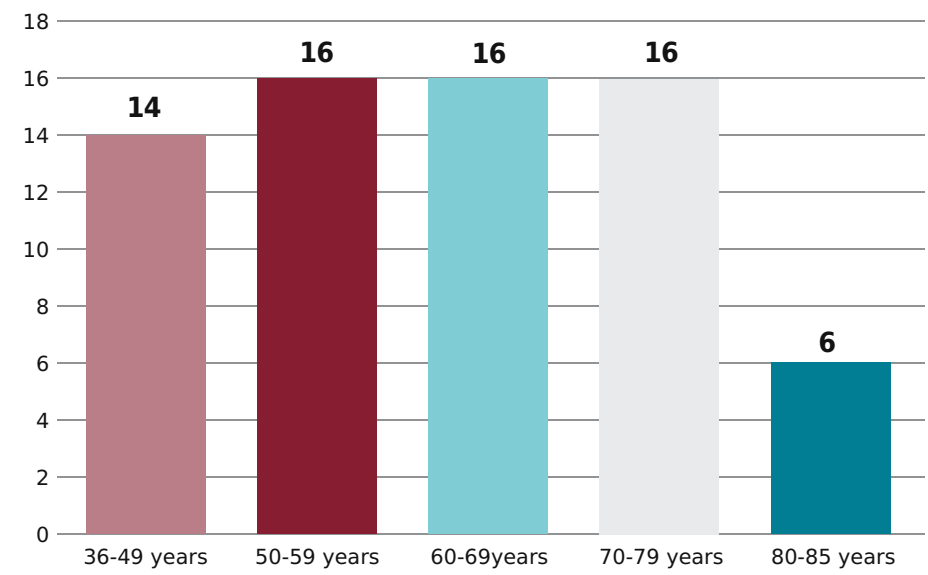

Figure 1. Distribution of patients by age intervals. Of note is that the age groups are well balanced and that our cohort also includes extreme ages, with 14 patients in the 36-49 age interval and 6 patients in the 80-85 age interval

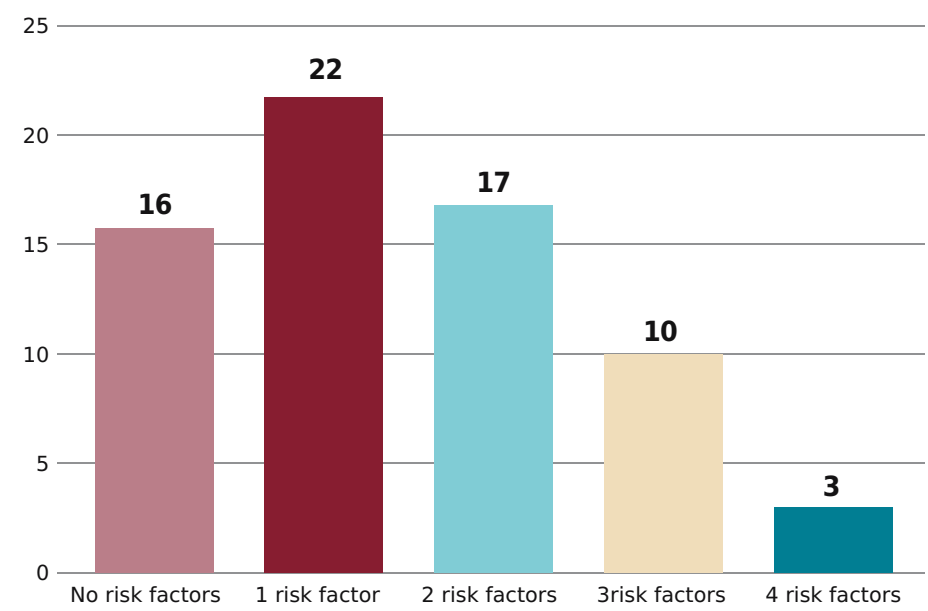

Figure 2. Cardiovascular risk factors in the cohort. Notice that $76 \%$ (52) of the patients had at least one risk factor

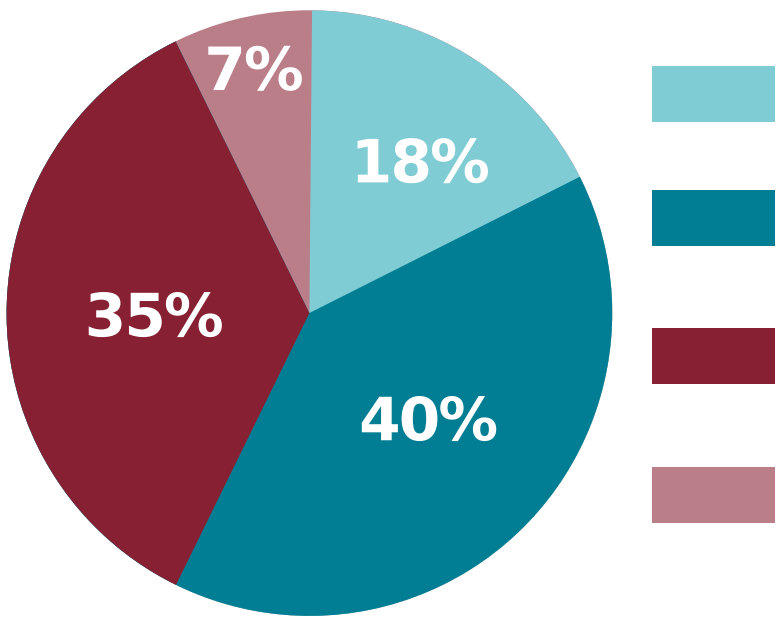

Killip Class I (no signs of congestion)

Killip Class II (crackles only in the lower half of the lung fields, possible S3)

Killip Class III (crackles more than halfway up the lung fields, pulmonary edema

Killip Class IV (cardiogenic shock)

Figure 3. Prevalence of Killip Classes at presentation. Note that $40 \%$ of the patients with restenosis presented as Killip Class II and 35\% as Killip Class III, while only 18\% presented as Killip Class I. 


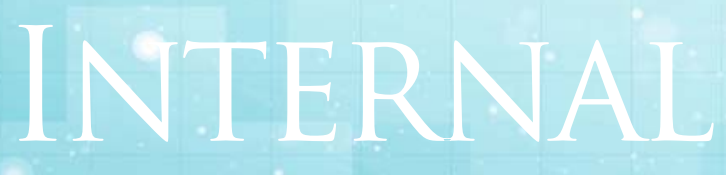

Original Papers

prevalence than we anticipated. Arterial hypertension (HTN) was the most prevalent cardiovascular risk factor, which is not surprising, considering that in Romanian patients HTN is underdiagnosed and only $30,8 \%$ of Romanian patients with HTN reach their target values ${ }^{(6)}$. Smoking was also highly prevalent in our cohort. It is known that current smoking increases the risk of restenosis in STEMI patients undergoing sirolimus-eluting stent implantation ${ }^{(7)}$. Apart from the usual cardiovascular risk factors, the clinical setting ( $\mathrm{PCl}$ of infarct-related lesions) is itself a risk factor, which is associated with a high incidence of angiographic recurrence (often silent), higher than in the case of $\mathrm{PCl}$ for stable lesions ${ }^{(8)}$. It is worth mentioning that our cohort included patients of all ages, in balanced proportions. Therefore, we observed that ISR occurred at all ages, even in young patients, although age is a well established risk factor for $\mathrm{ISR}^{(9)}$. No data were found regarding restenosis in patients who underwent thrombolysis before PCI in STEMI, and it appears not to influence restenosis rates $^{(9)}$. The lesion related risk factors for restenosis include the length of the lesion, the location (ostial/ bifurcation) and the diameter of the vessel. In our cohort, the anterior descending artery was the most frequent site of ISR, followed by the right coronary artery. The anterior descending artery, particularly the ostium, is a frequent site for restenosis with major implications considering the large territory which it supplies ${ }^{(10)}$. Surprisingly, although the left main coronary artery is another frequent site for restenosis, we encountered only two such cases in our cohort. Furthermore, we observed that many ISR occurred in vessels with a diameter of less than $2,5 \mathrm{~mm}$, which is concurrent with the data from the literature ${ }^{(11)}$.

Stent-related risk factors for restenosis are well described in the literature, such as the type of stent, the length of the stent and the diameter of the stent. The literature clearly describes a relationship between the length of the stent and the risk for ISR, which we also observed for stents longer than $28 \mathrm{~mm}^{(5,12)}$. First-generation DES, especially those coated with sirolimus have had mixed results regarding the rates of restenosis, although they are now considered safe in terms of $\mathrm{ISR}^{(13,14)}$.

ISR is regarded as a paucisymptomatic entity. Recurrent angina is observed in a minority of patients, while others might present with acute coronary syndromes, or even sudden cardiac death(15). Therefore, the symptomatology in ISR is not specific nor reliable. This is also what we observed in our cohort, where only a minority of patients had recurrent angina (11\%), even though 98,5\% had restenosis greater than $70 \%$. The explanation is complex and could comprise different aspects, such as: the development of collateral vessels, myocardial ischemic preconditioning or a modified angina 
threshold. Of course, all of these observations will serve as a starting point for a further, larger study, which will hopefully deliver some statistically significant results.

\section{Conclusions}

Based on our observations, we would like to draw some conclusions:

- HTN was the most commonly observed cardiovascular risk factor in patients with ISR (61\%), followed by dyslipidemia (60\%)

- ISR occurred at all ages.

- $76 \%$ of the patients with ISR had at least one cardiovascular risk factor and $44 \%$ had at least two cardiovascular risk factors.

- The ADA was the most common site for ISR (46\%).

- Killip Class II was the most common form of presentation for patients with STEMI who developed ISR (40\%).

- ISR was more common in vessels with a diameter of less than $2,5 \mathrm{~mm}$ (66\%).

- Recurrent angina was observed in only $11 \%$ of the patients with ISR.

- Further studies are required in order to establish the statistical significance of these observations.

\section{References}

1. WHO -Cardiovascular Diseases fact sheet

2. Jernberg $T$, Johanson $P$, Held $C$, et al. Association between adoption of evidence-based treatment and survival for patients with ST-elevation myocardial infarction. JAMA. 2011;305(16):1677-1684. doi:10.1001/ jama.2011.522

3. Serruys PW, Luijten HE, Beatt KJ, Geuskens R, de Feyter $P$ J, van den Brand $M$, Reiber JHC, ten Katen $H J$, van Es GA, Hugenholtz PG. Incidence of restenosis after successful coronary angioplasty: A time-related phenomenon: A quantitative angiographic study in 342 consecutive patients at 1, 2, 3, and 4 months. Circulation 1988;77:361-371

4. Fishman RF, Kuntz RE, Carrozza JP, Jr, et al. Long-term results of directional coronary atherectomy: predictors of restenosis. J Am Coll Cardiol 1992;20:1101-10.
10.1016/0735-1097(92)90365-T

5. Buccheri D, Piraino D, Andolina $G$, Cortese $B$. Understanding and managing in-stent restenosis: a review of clinical data, from pathogenesis to treatment. J Thorac Dis. 2016;8(10):E1150-E1162. doi:10.21037/ jtd.2016.10.93

6. Dorobantu M, Darabont RO, Badila E, Ghiorghe S. Prevalence, Awareness, Treatment, and Control of Hypertension in Romania: Results of the SEPHAR Study. Int J Hypertens. 2010;2010:970694. Published 2010 Feb 1. doi:10.4061/2010/970694

7. Ma S, Yang D, Zhang $X$, Tang B, Li D, Sun $M$, et al. Comparison of restenosis rate with sirolimus-eluting stent in STEMI patients with and without diabetes at 6-month angiographic follow-up. Acta Cardiol. 2011;66(5):603-606 8. Meijer A, Verheugt FWA, Werter CJPJ, Lie KI, Van Der Pol JML, Van Eenige MJ. Aspirin versus coumadin in the prevention of reocclusion and recurrent ischemia after successful thrombolysis: a prospective placebo-controlled angiographic study: results of the APRICOT study. Circulation.1993; 83:1524-1530.

9. Cho JY. Identification of Risk Factors Influencing InStent Restenosis with Acute Coronary Syndrome Presentation. Chonnam Med J. 2017;53(3):203-210. doi:10.4068/cmj.2017.53.3.203

10. Frierson JH, Dimas AP, Withlow PL, et al. Angioplasty of the proximal left anterior descending coronary artery: initial suc- cess and long-term follow-up. J Am Call Cardiol. 1992;19:745- 751.

11. Moses JW, Leon MB, Popma JJ, Fitzgerald PJ, Holmes DR, O'Shaughnessy C, Caputo RP, Kereiakes DJ, Williams DO, Teirstein PS, Jaeger JL, Kuntz RE. Sirolimus-eluting stents versus standard stents in patients with stenosis in a native coronary artery. N EnglJ Med. 2003; 349: 1315-1323.

12. Nita D, Gurzun MM, Chiriac L, Cirstea Al, Parepa RI, Barbilian AG. Impact of stent diameter and length of instent restenosis after bare metal stent implantation. Romanian Biotechnological Letters, vol. 22, No. 2, 2017.

13. Abizaid A. Sirolimus-eluting coronary stents: a review. Vasc Health Risk Manag. 2007;3(2):191-201. doi:10.2147/vhrm.2007.3.2.191

14. Sheiban I, Chiribiri A, Galli S, Biondi-Zoccai G, Montorsi $P$, Beninati $S$, Fabbiocchi $F$, Moretti $C$, Omedè $P$, Trabattoni $D$, Lotrionte $M$, Trevi GP, Bartorelli $A L$. Sirolimus-eluting stent implantation for bare-metal instent restenosis: is there any evidence for a late catch-up phenomenon? J Cardiovasc Med (Hagerstown). 2008 Aug;9(8):783-8. doi: 10.2459/JCM.0b013e3282fb7882. PMID: 18607241.

15. Lee MS, Pessegueiro A, Zimmer R, Jurewitz D, Tobis J. Clinical presentation of patients with in-stent restenosis in the drug-eluting stent era. J Invasive Cardiol. 2008 Aug;20(8):401-403. 